\title{
Taxation and Inflation in Nigeria: An Empirical Analysis
}

\author{
Osasu Obaretin ${ }^{1 *} \quad$ Sadiq Oshoke Akhor ${ }^{2}$ \\ 1.Department of Accounting, Faculty of Management Sciences, University of Benin \\ 2.Bursary Department, College of Education, Igueben
}

\begin{abstract}
This study examines the role of taxation as a tool for addressing the challenges of inflation in Nigeria. Data for this study were gathered from Annual Abstract from the Office of National Bureau of Statistics and the office of the Federal Inland Revenue Service for a period of twenty years (1994 to 2014). The data gathered were thereafter analyzed using the error correction model (ECM) and from the analysis the paper revealed that all the variables (companies income tax, value added tax and custom and excise duties) had a positive and a non-significant relationship with inflation. However, from the conclusion the paper recommended that the government and policy makers should formulate an active tax policy to curb the issue of inflations in Nigeria and there should be a review of the periods where Nigeria witnessed lower inflation rates to see whether or not taxation (indirect taxes) played a role in ensuring the low inflation rate and then the successive introduction of the policies as it relates to taxation in the subsequent period.
\end{abstract}

Keywords: companies income tax, value added tax, custom and excise duties, inflation

DOI: $10.7176 / \mathrm{RJFA} / 10-4-11$

\section{Introduction}

In the Nigeria economic history, the maintenance of stable price has remained one of the major macroeconomic difficulties confronting the Nigerian government (Fatukasi, 2004). Emphasising that, this has caused different governments to put in place measures to cushion the effect of general price increases which is termed "inflation". By definition inflation is the persistent, continuous and substantial increase in the general price level of the economy (Jhingan, 2002). This connotes that the rise or increase in the price level must be seen as sustained, constant and enduring and should affect almost every commodity and should be of a permanent nature (Fatukasi, 2004). Jhingan (2002), posited that Demberg and McDougall were more explicit when they referred to inflation as a continuous rise in prices, measured by the Consumer Price Index (CPI) or the implicit price deflator for Gross National Product.

The effect of inflation in the Nigerian economy is overwhelming as it has been challenging for the country currency to serve as an avenue of exchange and a custodian of value without having a negative effect on output, income distribution and employment. Bawa and Abdullahi (2012) observed that inflation has many adverse effects amongst which are: imposition of welfare costs on the society, impeding efficient and effective resources allocation, discouraging investment and savings by creating uncertainties about future prices, inhibiting financial development by making intermediation more expensive, hitting the poor excessively because of the fact that they do not hold financial assets that safeguards against inflation and thereby reducing a country's competitiveness in the international market.

Orji, Anthony-Orji and Okafor (2015) also observed that in Nigeria, the trend of inflation over time has been non-linear adding that the inflation rate which stood at 21.4 percent in 1980 and drastically reduced to 7.2 percent in 1981 had by 1983, witnessed a rate upsurge to about 41 percent. They added the era of the Structural Adjustment Programme (1986 - 1992), saw the of inflation averaging 31.5 percent while from 1995 to 2007, it stood at an average of 12.3 percent and then 12 percent during the 2008 to 2011 period. Recent data available from the International monetary Fund (2015), shows that between the period of 2009 to 2014, inflation rate has on the average stood at 10.98 percent.

Despite the cascading effects of inflation, government has been empowered with tools and policies to effectively cushion the adverse effect of inflation on the economy and restore the economy to a balance. One of the effective tools or policy available to government is the fiscal policy. Abata, kehinde and Bolarinwa (2012) noted that government policies of fiscal and monetary are totally linked in macroeconomic management as developments in one sector directly affects development in the other sector. They argued that "fiscal policy is central to the health of any economy, as government's power to tax and to spend affects the disposable income of citizens and corporations, as well as the general business climate". Atan (2013), noted that taxation is a primary tool of economic management adding that taxation usually in combination with some other viable policy instruments can be used to steer the nation in the course that is desired. He further explained that if the nation economic is facing depression, the government could use tax policy to restore the system and cause a recovery while on the other hand, if the economy is experiencing inflationary pressures, taxation could be used to reduce the pressures and stabilise the economy. 


\subsection{Statement of the Research Problem}

It is a well-known fact that Nigeria relies heavily on imports and foreign exchange transactions to sustain the economy. Trade which is one of the major business activities in the country seems to be hindered due to inflationary pressures arising from increased exchange rates and general rise in the cost of living. Fatukasi (2004), noted that since the mid-1960s, inflation has become an stern and controversial issue in Nigeria. He noted that the recent rates of inflation which have been a cause of great concern to many, has led to major economic distortions in the country, seeing to the increase in prices of goods and services, reduction in operating capacity due to the fact that the existing level of operations can no longer be sustained at the current price, and a host of other factors. Chimobi (2010), observed that the high level of inflation has disrupted smooth functioning of the market economy while at the individual level, exerting a heavy toll on those with fixed incomes

Ijaiya (2000), also observed that despite the policies introduced by successive governments in Nigeria to reduce inflation, the policy measures have had little or no effect on inflation, owing to policy inconsistency, mismanagement and corruption. He further added that one of the consequences of the failure to reduce inflation has been a continuous increase in the poverty rate as a result of the fact that the increase in inflation has affected the purchasing power of most people; including wage earners and pensioners. The fall in the purchasing power has made it difficult for the people to buy some of their basic needs with which they can escape poverty.

Studies that have been conducted in this area are basically on inflation and economic growth in Nigeria (e.g. Bakare, Kareem \& Onyelekan, 2015; Chimobi, 2010; Chude \& Chude, 2015; Osuala, Osuala \& Onyeike, 2013; and Umaru \& Zubairu, 2012) but scarce studies exist in the area of taxation and inflation directly in Nigeria. According to the Central Bank of Nigeria (CBN, 2011pp. 8), "reduction in taxes raises disposable income thereby increasing private consumption and investment expenditure. Reduction in tax level could be an effective measure during recession/depression. On the other hand, an increase in taxes tends to reduce disposable income thereby, limiting consumption and investment expenditure." Therefore, in recognition of the usefulness of taxation in curbing inflation, this study seeks to empirically examine the effect of direct taxes on inflation in Nigeria.

\section{LITERATURE REVIEW}

\subsection{Concept of Inflation}

Inflation is defined as a generalized increase in the level of price sustained over long period in an economy (Lipsey \& Chrystal, 1995), that is, a unrelenting rise in the price levels of commodities and services, leading to a fall in the nation currency's purchasing power. According to Fatukasi (2004), not every rise in the price level is seen as inflation, consequently for an increase in the general price level to be considered inflation; such an increase must be endured, constant and sustained.

According to Hossain et al. (2012) "high inflation is bad for an economy because of its adverse effect on economic performance, zero inflation is equally harmful because it will lead to eventual stagnation of the economy since its presence at a mild level is needed for economic growth". The predicament of inflation is not restricted to national boundaries neither is it restricted to market economies of the world; it is also a topical issue in the develop market economies, and since it is by no means a new issue or event, over time, its management has become the unquestioned mantra of economic policymakers globally.

Measuring inflation has been a complex issue for government statisticians. To achieve this, a number of goods and services that are representative of the nation are put together in what is referred to as market basket (Investopodia, 2016). The cost of this market basket is then compared over a period of time; this results in a price index which is the cost of basket today as a percentage of the cost of the identical basket in the first year.

Nigeria as a nation is by no means untouchable by the danger of inflation. Hence, after an substantial economic performance in the beginning of the 1970s, the Nigerian economy observed some uneasy moments in the late 1970s to mid-1980s. Severe pressures built up in the nation mainly because of the expansionary fiscal policy of the federal government during these period. This was followed by high monetary expansion as the enormous government deficit was financed basically by the Central Bank of Nigeria which was compounded by the transfer of government sector deposits to the banks and the aftereffect was increase in their free reserves with unfavorable consequences on the general price level.

The effect of inflation on an economy cannot be over emphasized as shown by many studies conducted on this issue. Wikipedia (2016), substantiated that inflation affects an economy in both positive and negative ways but the negative effect outweigh that of the positive's. Positive in the sense that it leads to reduction in the real burden of the public and private debt, reduction of unemployment due to nominal wage rigidity and lastly, keeping of nominal interest rates above zero so that the central bank can adjust interest rates to stabilize the economy. Its harmful effects include uncertainty over future inflation which may discourage investments and savings, an increase in the opportunity involved in cash holding and if inflation were rapid enough, shortage of goods occurs as consumers begin hoarding out of future raise in price. 


\subsection{Concept of Taxation and Tax}

the enormous task of government responsibility to its citizens and the need to enhance the standard of living calls for government serious financial involvement in a nation economic development. It has also be shown that government of many developing countries have not be able to provide adequate public services due to several reasons. The most paramount of them is the inadequate revenue. And one sure way of generating this revenue is through the instrumentality of taxation.

In Nigeria, the fluctuations in the price of crude oil in recent years has led to declined in fund available for the allocation to the federal, state and local government. Therefore, for the local and state government to source adequate fund internally, taxation has become a matter of utmost importance. In most countries of the world, the primary objective and purpose is essentially to generate revenue to satisfy the needs of the government such as in provision of services like defense, law and order, health services and education. Revenue from taxation can also be spent on capital project, creating social and economic infrastructure. All these have been pampered by a number of factors globally but tax evasion unarguably is considered to be the most challenging in developing countries such as Nigeria. Soyode and Kajola (2006) define tax as "a compulsory exaction of money by a public authority for public purpose and that taxation is a system of raising money by the government by means of contributions from individual person or corporate body". Anyua, (1996) opined that the most essential thing is that "tax is a pecuniary burden laid upon individuals or persons or property to support the government and is a payment exacted by legislative authority".

The collection of tax by government is not tied to any direct and specific benefit to the taxpayer. However, it is upon this characteristic that Soyode and kajola (2006), distinguishes a tax from other forms of government collections such as fines, fees and penalties. A fines and penalties are collections by way of penalty for infringement of state laws or regulations, while a fee is an amount paid in return for a specific and measurable service. Although tax payment is not basically tied to the conferment of any direct and specific benefit to the taxpayer, it is perfectly recognized by (taxpayer and the tax collector that the judicious use of tax revenue by the government for the public good is the quid pro quo for taxing the citizens

\subsection{Empirical Review \\ 2.3.1 Taxation and Inflation}

There is a dearth in literature on the topic of taxation and inflation both by in Nigerian scholars and scholars from other part of the world. However, studies that may align with the topic one way or the other are therefore brought to light under this section of the empirical review.

Atan, (2013) carried out a study on tax policy, inflation and unemployment in Nigeria. For a period of 1970 to 2008 using the ordinary least square method the study revealed that historical trends inflation and unemployment had no significant response to tax policy within the stated period. The study further revealed that during some period of lower taxes recorded lower inflation while unemployment variation was not premised on weather taxes were increased or lowered. In conclusion he stated that taxes have a negative effect on inflation in Nigeria.

Olatunji, (2013) carried out a study to examine the effect of VAT the revenue generation in Nigeria and the view of the citizen on VAT and Inflation. He adopted the descriptive research method for the study under review. However, the study employed both primary as well as secondary data. For the primary data the study made use of a well structured questionnaire and oral interview while for the secondary data it was gathered from federal inland revenue service annual reports, the Nigeria tax news, value added Tax Decree, Federal office of statistics, annual abstract of statistics, Federal ministry of finance Abuja; quarterly performance report of the Economy and budget of Economic growth and development, and daily newspaper, Guardian, Thisday newspaper and Punch newspaper. The study concluded that VAT has not affected either increase or decrease in inflation rate in Nigeria within the period under review. Thereafter, recommended that for any fiscal policy to succeed, it must be properly planned, the duration depending on the level of the development of the country should be reasonable, and also effective communication should be used to improve the quality of its implementation and increase the revenue collected. Suggesting also that there should be an upward review of the rate of VAT in other to meet the current needs of the country.

However, the study by Bakare, Adesanya and Bolarinwa, (2014) empirically investigated the relationship between budget deficit, money supply and inflation in Nigeria. To achieve this, macroeconomic variables for the study were gathered for a period (37) years that is 1975 and 2012. They engaged quantitative methodological framework and basically drew on econometric procedure to find the relationship between inflation rate, growth rate of money supply, growth of budget deficit/GDP and growth of external debt/GDP. The error correction model was used in analysis the data gathered and from the analyses the study concluded that the overall result between inflation rate and growth of money supply, growth of budget deficit to gross domestic product and growth of external debt to gross domestic product showed that the study is statistically significant at $5 \%$ level of significance.

Moreso, Dockery, Ezeabasili and Herbert (2012) examined the relationship between fiscal deficit and inflation in Nigeria. The study employed a modeling approach which incorporated co- integration techniques and 
structural analysis. The findings of the study revealed a positive but insignificant relationship between inflation and fiscal deficit in Nigeria for the period considered which was between 1970 to 2006. However, this period was considered critical because of the persistent inflationary trends in Nigeria.

Surjaningsih et al. (2012) conducted a study on the effect of fiscal policy on output and inflation in Indonesia. The study considered the impacted of discretionary fiscal policy on the volatility of output and inflation. The study covered a time frame of 19 years (1990 to 2009) and the vector error correction model was used for the study. However, from the empirical analysis, the study revealed that there exist a co-integration relationship the spending of government and taxes with regards to output in the long run. Stating that, unlike government spending, taxation has a positive impact on economic growth in the long run. On the other hand, the short run suggested that " an increase in government spending has a positive impact on output unlike taxation with a negative impact on output. They further stated that there is greater impact of government spending on output in the short run compared to tax policies and that output government spending is more effective in stimulating economic growth particularly during the period of recession when compared to tax policies.

Anichebe (2015), examined the implication of tax policy on inflation in Nigeria. The study period covered between 1981 to 2012 (32 years), relevant data for the study were gathered from Central of Bank of Nigeria annual report. Thereafter, a combination of the Johansen test and ordinary least square (OLS), granger causality/Block exogeneity wald test were conducted. The findings of the study revealed that there exist a long run relationship between tax policy and inflation in Nigeria. Stressing that personal income tax rate has a negative effect on inflation within the reviewed period. While on the other hand, company income, property tax, consumption tax exerted significant positive impact on inflation.

\subsection{Objectives of the Study}

The broad objective of this study is to examine the effect of indirect taxes on inflation in Nigeria. To achieve this specific objectives are stated thus:

- $\quad$ to evaluate the relationship between Companies' Income Tax and Inflation in Nigeria;

- $\quad$ to examine the effect of Value Added Tax on Inflation in Nigeria; and

- $\quad$ to find out the relationship between Customs and Excise Duties and Inflation in Nigeria.

\subsection{Statement of the Research Hypotheses}

The hypotheses which this paper sets out to empirically evaluate are herein stated in the null form below: Research Problem 1:

$\mathrm{H}_{0}$ : there is no significant relationship between companies income tax and inflation in Nigeria.

H1: there is a significant relationship between companies income tax and inflation in Nigeria.

\section{Research Problem 2:}

$\mathrm{H}_{0}$ : $\quad$ value added tax has no significant effect on Inflation in Nigeria.

H1: $\quad$ value added tax has significant effect on inflation in Nigeria

\section{Research Problem 3:}

$\mathrm{H}_{0:} \quad$ there is no significant relationship between customs and excise duties and inflation in Nigeria.

H1: there is a significant relationship between customs and excise duties and inflation in Nigeria

\section{Methodology}

This study employed survey research design in evaluating the effect of as a tool for curbing inflation in Nigeria with primary emphasis on indirect taxes in Nigeria. Secondary data were obtained from various sources, such as the Nigeria Bureau of Statistics and the office of the Federal Inland Revenue Service. The study covers Nigeria's economy using a time series data analysis relating to Taxation and Inflation for the years 1994 to 2014. These macroeconomic variables collected were analyzed using Error Correction Model (ECM) method of analysis with the aid of E-views 8.1 statistical package. The Augmented Dickey Fuller (ADF) technique was applied on the variables to test for stationarity of variables.

\subsection{Measurement of Variables}

For the purpose of this paper, the following measures and proxies are adopted for the variables:

Inflation $=$ measured by Consumer Price Index (CPI)

Taxation $=$ Measured by Value Added Tax (VAT) revenue, Companies' Income

Tax (CIT) revenue and Customs and Excise Duties (CED) revenue.

\subsection{Model Specification}

The model used for this study is a self-built model whose derivation is based on the objectives and hypotheses of the study. The functional and econometric model is herein specified:

$\mathrm{INF}_{\mathrm{t}}=\mathrm{f}\left(\mathrm{VAT}_{\mathrm{t}}, \mathrm{CIT}_{\mathrm{t}}, \mathrm{CED}_{\mathrm{t}}\right)$ 
$\mathrm{INF}=\beta_{0}+\beta_{1} \mathrm{VAT}+\beta_{2} \mathrm{CIT}+\beta_{3} \mathrm{CED}+\mu_{\mathrm{t}} \ldots$

Where:

$\beta_{0}=$ constant

$\beta_{1}$ to $\beta_{4}=$ Parameter Estimate

$\mathrm{VAT}=$ Value Added Tax

CIT $=$ Companies Income Tax

$\mathrm{CED}=$ Customs and Excise Duties

$\mu_{\mathrm{t}}=$ Stochastic Error Term.

The above model specifies Inflation (INF) as the dependent variable while Value Added Tax (VAT), Companies

Income Tax (CIT), and Customs and Excise [Duties (CED) as the independent variables.

ESTIMATION RESULTS AND DISCUSSION OF FINDINGS

Table 1: Descriptive statistics for 1994-2014

\begin{tabular}{|l|l|l|l|l|}
\hline & INF & CIT & CED & VAT \\
\hline Mean & 16.56190 & 316.6891 & 287.0871 & 280.9005 \\
\hline Median & 11.90000 & 130.7819 & 195.5000 & 163.2977 \\
\hline Maximum & 76.80000 & 1173.491 & 977.0900 & 802.9647 \\
\hline Minimum & 0.200000 & 12.27480 & 18.29460 & 7.260800 \\
\hline Std. Dev. & 16.93731 & 354.6062 & 274.6161 & 278.2952 \\
\hline Skewness & 2.672964 & 1.054542 & 1.294104 & 0.775342 \\
\hline Kurtosis & 9.429340 & 2.883211 & 3.546032 & 2.108737 \\
\hline Jarque-Bera & 61.17594 & 3.904143 & 6.122346 & 2.799097 \\
\hline Probability & 0.000000 & 0.141980 & 0.046833 & 0.246708 \\
\hline Sum & 347.8000 & 6650.471 & 6028.829 & 5898.911 \\
\hline Sum Sq. Dev & 5737.450 & 2514911 & 1508280 & 1548964 \\
\hline Observations & 21 & 21 & 21 & 21 \\
\hline
\end{tabular}

Source: E-views Output (2018)

The descriptive statistics of the variables used in the analysis presented in Table 1 explains the range, minimum, maximum, mid values, spread and normality of the variables. The mean valve of inflation is $16.56190 \%$ for the period under review while the minimum and maximum values are $0.200000 \%$ and $76.80000 \%$ respectively; its standard deviation stood at $16.93731 \%$ which shows that INF is not widely dispersed from the mean. All the variables used for the study including the dependent variable INF have positive means and are all positively skewed.

\subsection{Unit Root Testing}

The unit root test is conducted to test for the stationary of the variables. The reason for this is to ensure that the data being used are reliable and useful for decision making. It is conducted using the Augmented Dickey Fuller (ADF) Test. Using the 5\% level of level of significance, the rule is that the ADF test statistic must be greater than the test of critical values at $5 \%$ in absolute values and the p-value of the ADF test statistic must be significant. The results are presented below:

Table 2: Unit Root Test Presentation

\begin{tabular}{|l|l|l|l|l|l|}
\hline Form & Variables & ADF test statistics & $5 \%$ test critical value & p-value & Remark \\
\hline Level & CED & 4.710868 & 3.020686 & 1.0000 & Not stationary \\
\hline & CIT & 4.543523 & 3.065585 & 1.0000 & Not stationary \\
\hline & INF & 3.607576 & 3.065585 & 0.0182 & Stationary \\
\hline & VAT & 1.988486 & 3.040391 & 0.2886 & Not stationary \\
\hline First Difference & CED & 1.442615 & 3.029970 & 0.5398 & Not Stationary \\
\hline & CIT & 0.811257 & 3.081002 & 0.9904 & Not stationary \\
\hline & VAT & 1.589162 & 3.052169 & 0.4662 & Not stationary \\
\hline Second Difference & CED & 5.818359 & 3.040391 & 0.0002 & Stationary \\
\hline & CIT & 3.305427 & 3.081002 & 0.0334 & Stationary \\
\hline & VAT & 6.150909 & 3.040391 & 0.0001 & Stationary \\
\hline
\end{tabular}

\section{Source: E-views Output (2018)}

From the unit root presentation in table 2 above, it was observed that inflation (INF) was stationary at level while Customs and Excise Duties (CED), Companies Income Tax (CIT) and Value Added Tax (VAT) were stationary at the second difference at the $15 \%$ level of significance. 
Regression Analysis, Table 3: Error Correction Model result

\begin{tabular}{|l|l|l|l|l|l|}
\hline Variable & Coefficient & Std. Error & t-statistic & Prob & Status \\
\hline C & -6.673975 & 2.833872 & -2.349223 & 0.0329 & \\
\hline D (CIT) & 0.038558 & 0.030417 & 1.267656 & 0.2242 & Not Significant \\
\hline D(CED) & 0.014011 & 0.038634 & 0.362660 & 0.7219 & Not Significant \\
\hline D(VAT) & 0.010185 & 0.061582 & 0.165382 & 0.8709 & Not significant \\
\hline ECT(-1) & -0.569584 & 0.112402 & -5.067387 & 0.0001 & Significant \\
\hline R-squared & 0.662054 & & Adjusted R-squared & 0.571936 & \\
\hline f-statistic & 7.346460 & & & & \\
\hline Prob. (f-statistic) & 0.001746 & & Durbin-watson stat & 2.559357 & \\
\hline
\end{tabular}

Source: E-views Output (2018)

From the error correction model result in table 3 above, the coefficient of that variation and determination which is depicted R-squared is 0.66 which suggest that the variables employed in the model accounts for or is responsible for about $66 \%$ of the systematic variation in the dependent variable inflation(INF) while the remaining $34 \%$ is unaccounted for be the model and is therefore captured by the stochastic error term. The coefficient of determination when adjusted for degrees of freedom further reduces to $57 \%$ thus reflecting the fact that the model is nicely fitted. an examination of the F-statistic reveals a value of 7.346460 having a P-value of 0.001746 which therefore indicates that the model is statistically significant and that the independent variables (CED,CITAND VAT) selected in the model can jointly influence or impact the behavior of the dependent variable inflation(IFN) in the long run. The Durbin Watson statistics which revealed a value of 2.559357 indicates the absence of first order serial correlation or autocorrelation thus signifying that the model is free from bias and that the result can be depended upon and used for decision making .

Further examination of the analysis result reveals that all the independent variables (CIT,CED, VAT) has a positive relationship with inflation (IFN) implying that an increase in any of them will lead to an increase in inflation (IFN). With regard to individuals (CIT,CED VAT) exhibited a significant relationship with inflation (IFN) at the 5\% significant level because all their p-values were greater than 0.05 . the error correction term which is denoted ECT(-1) fulfilled the criteria of a long run relationship among the variables as the coefficient was both negative and its p-value. Significant (less than 0.05 ) at the $5 \%$ level of significance.

\subsection{Discussion of Findings}

Following from the result of the analysis, it was seen that Customs and Excise Duties (CED) had a positive and insignificant relationship with inflation (INF) implying that an increase in CED revenue necessitated by an increase in imports for any given year is expected to give rise to an increase in inflation. However, CED has no significant impact on inflation in Nigeria. Companies' Income Tax (CIT) also exhibited a positive and insignificant relationship with Inflation (INF) which suggests that the higher the CIT revenue generated by the government which may be as a result of increase in economic activities, the higher the level of inflationary pressures on the Nigerian economy expected. However, because the relationship was insignificant, we can say that CIT does not exert a significant effect or impact on inflation. Value Added Tax (VAT) which is a tax on consumption was also positive and insignificant. This means that the higher level of consumption, the higher the level of VAT generated and invariably, the higher the level of inflation in Nigeria. This finding is consistent with that of Olatunji (2013) and Anichebe (2015)

\section{Conclusion and Recommendations}

This study empirically evaluated the relationship between taxation and inflation in Nigeria. By employing the time series data and the error correction model method of estimation, it made companies Income Tax (CIT), Customs and Excise Duties (CED) And Value Added Tax(VAT) as Proxies for taxation. The results of the analysis carried out revealed that all the variables had a positive and a non-significant relationship with inflation. This study expands the little or non-existent literature on the relationship between taxation and inflation in Nigeria and therefore hopes that with the under-mentioned recommendations, the menace of inflation will be curbed to its barest minimum. And the recommendations are:

1. The government and policy makers should formulate an active tax policy to curb the issue of inflations in Nigeria. This means that government should come up with a tax strategy on how to curb the menace of inflation in an incremental way.

2. There should be a review of the periods where Nigeria witnessed lower inflation rates to see whether or not taxation (indirect taxes) played a role in ensuring the low inflation rate and then the successive introduction of the policies as it relates to taxation in the subsequent period.

3. There should be a sector by sector analysis of contributions to inflation and ensure that the sectors that contributes more to inflation is tackled headlong and brought very low as much as possible. 


\section{References}

Abata ,M.A., Kehinde, J.S..\& Bolarinwa, S.A., (2012). Fasical/monetary policy and economic growth in Nigeria: A theoretical exploration. International Journal of Academic Research in Economics and Management Sciences, 1(5), 75-88.

Anichebe, A.S. (2015). Implication of tax policy on inflation in Nigeria (1981 -2012). Journal of Developing Country Studies, 5(2),103-113

Anyua, I.A., (1996). Nigeria tax law. Ibadan: Spectrum Law Publishing.

Atan, J.A., (2013). Tax policy, inflation and unemployment in Nigeria (1970-2008). European Journal of Business and Management, 5(15), 114-129.

Bakare, H., Kareen,R., \& Oyelekan, B., (2015). Effects of inflation rate on economic growth in Nigeria (19862014). Journal Developing Country Studies, 5(8), 153-160

Bakare, I.A.O., Adesanya, O.A., \& Bolarinwa, S.A.,(2014).Empirical investigation between budget deficit, inflation and money supply in Nigeria. European Journal of Business and Social Sciences, 2(12), 120-134.

Bawa, S., \& Abdullahi, I.S. (2012).Threshold effect of inflation on economic growth in Nigeria.CBN Journal of Applied Statistics. 3(1), 43-63.

Chimobi, O.P., (2010). Inflation and economic growth in Nigeria. Journal of Sustainable Development, 3(2), 159166.

Chude, D.I., \& Chude, N.P.(2015). Impact of inflation on economic growth in Nigeria (2000-2009). International Journal of Business and Management Review, 3(5), 26-34.

Dockery, E., Ezeabasili, V.N.,\& Herbert,W.E.(2012). On the relationship between fiscal deficts and inflation: Econometric evidence for Nigeria. Economics and Finance Review. 2(7), 17-30.

Fatukasi, B., (2004). Determinants of inflation in Nigeria: An empirical analysis. International Journal of Humanities and Social Science, 1(8), 262-271.

Hossain, E., Ghosh, B.C., \& Islam, K., (2012). Inflation and economic growth in Bangladesh, international Refereed Research Journal, 3(4), 85.

Ijaiya, B.T. (2000). Inflation and poverty in Nigeria: A calibration analysis. International Journal of Business and social Science, 7(1), 60-76.

Jhingan, M.L. (2002). Macroeconomic Theory. (10 ${ }^{\text {th }}$.ed). Vrinda Publications Ltd: New Delhi.

Lipsey R.G., \& Chrystal, K.A. (1995). An introduction to positive Economics $\left(8^{\text {th }}\right.$ Ed). Oxford: Oxford University Press, N.Y.

Olatunji, O.C. (2013). Valve added tax (vat) and inflation in Nigeria (1990 to 2003). Asian Journal of Humanities and Social Science, 1(1), 123-135

Orji, A., Anthony-Oriji, O.I., \& Okafor, J.C.,(2015). Inflation and employment nexus in Nigeria: Another test of Philips curve. Asian Economic and Financial Review, 5(5), 766-778

Osuala, A.E., Osuala, K.I., \& Onyeike, S.C.,(2013). Impact of inflation on economic growth in Nigeria. International Journal of Humanities and Social Science invention 2(6),16-26.

Soyode, L., \&Kajola, S.,(2006). Taxation: Principles and practice in Nigeria. Ibadan: Silicon publishing company.

Surjaningsih, N., Utari, G.A.D., Trisnanto, B.,(2012).The impact of fiscal policy on the output and inflation. Bulletin of monetary Economics and Banking, 367-396.

Umaru, A., Zubairu, A.A(2012). Effect of inflation on the growth and development of the Nigerian economy: An empirical analysis .international Journal of Business and social science, 3(10), 183-191. 


\section{APPENDIX I}

\begin{tabular}{|l|l|l|l|l|}
\hline Years & INF & VAT & CIT & CED \\
\hline 1994 & 76.8 & 7.2608 & 12.2748 & 18.2946 \\
\hline 1995 & 51.6 & 20.761 & 21.8783 & 37.364 \\
\hline 1996 & 14.3 & 31 & 22 & 55 \\
\hline 1997 & 10.2 & 34 & 26 & 63 \\
\hline 1998 & 11.9 & 36.9 & 33.3 & 67.7 \\
\hline 1999 & 0.2 & 47.1 & 46.2 & 87.9 \\
\hline 2000 & 14.5 & 58.5 & 51.1 & 101.6 \\
\hline 2001 & 16.5 & 91.8 & 68.7 & 170.6 \\
\hline 2002 & 12.2 & 108.6 & 89.1 & 181.4 \\
\hline 2003 & 23.8 & 136.4 & 114.8 & 195.5 \\
\hline 2004 & 10 & 163.2977 & 130.7819 & 217.2 \\
\hline 2005 & 11.6 & 192.6565 & 170.2 & 232.8 \\
\hline 2006 & 8.5 & 232.6972 & 246.6718 & 177.7 \\
\hline 2007 & 6.6 & 314.5455 & 332.4439 & 241.4 \\
\hline 2008 & 15.1 & 401.7367 & 420.583 & 281.3 \\
\hline 2009 & 13.9 & 481.4073 & 595.1822 & 321.08 \\
\hline 2010 & 11.8 & 564.8916 & 657.3 & 438.3 \\
\hline 2011 & 10.3 & 659.1536 & 654.4482 & 602 \\
\hline 2012 & 12 & 710.5551 & 820.5655 & 728.2 \\
\hline 2013 & 8 & 802.6835 & 963.4508 & 833.4 \\
\hline 2014 & 8 & 802.9647 & 1173.491 & 977.09 \\
\hline
\end{tabular}

Source: CBN Statistical Bulletin and National Bureau of Statistics 